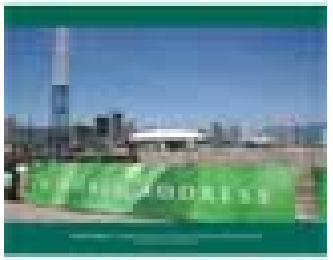

Urban Geography

\title{
The touristification of nightlife: some theoretical notes
}

\section{Jordi Nofre}

To cite this article: Jordi Nofre (2020): The touristification of nightlife: some theoretical notes, Urban Geography, DOI: 10.1080/02723638.2020.1855002

To link to this article: https://doi.org/10.1080/02723638.2020.1855002

册 Published online: 27 Nov 2020.

Submit your article to this journal

Џlll Article views: 132

Q View related articles ๘

View Crossmark data $\nearrow$ 


\title{
The touristification of nightlife: some theoretical notes
}

\author{
Jordi Nofre (iD) \\ Interdisciplinary Centre of Social Sciences, NOVA University of Lisbon, Lisbon, Portugal
}

\begin{abstract}
Agrowing number of authors have recently suggested a clear interaction between tourist gentrification and commercial gentrification. However, little scholarly attention has been paid to the growing interrelation between the nighttime leisure economy and urban tourism, along with all its complex forms of simultaneous interaction as fundamental driving forces of the current processes transforming the social, economic and cultural fabric of the central areas of many European cities. This short paper will argue that much more academic attention should be paid to how the touristification of nightlife is emerging as one of the most aggressive forms of material, symbolic and heritage dispossession of local communities within the central historic neighborhoods of many European cities.
\end{abstract}

\section{ARTICLE HISTORY}

Received 16 March 2020

Accepted 19 November 2020

\section{KEYWORDS}

Nightlife; touristification; dispossession; urban change

\section{Introduction}

Until the COVID-19 pandemic outbreak, every week of the year tens of millions of people across Europe would go out in the evening and at nighttime to dine, drink, and dance ... or just to meet their friends. Certainly, nightlife is central to the social and cultural life of our European society and is a source of vivid memories for many people (Haslam, 2015; Laughey, 2006). Traditional nightlife venues, such as bars, nightclubs and restaurants, live arts and dance venues, as well as those for late-night sports and recreation, are all integral to community well-being. But nightlife is much more than this: the nocturnal gymkhanas, amateur sport in the evening, house parties, botellón in public spaces or bingos, neighborhood theaters, and shisha associations - among other activities - represent alternative forms of nightlife that play a central role in the leisure practices of many people across Europe. However, while the economic value of nightlife has now been well documented, drawing primarily on British literature where it is referred to as "the night-time economy" (e.g., Bianchini, 1990, 1995; Chatterton \& Hollands, 2003; Roberts, 2006; Roberts \& Eldridge, 2009; Shaw, 2018), little academic attention - with a few brilliant exceptions such as Eldridge (2019) and Eldridge and Smith (2019) - has been paid to the expansion of the tourist-oriented nighttime leisure economy and its role as a driving force for the dramatic transformation of central areas of the largest European cities.

CONTACT Jordi Nofre $\otimes$ jnofre@fcsh.unl.pt $\Theta$ Centro Interdisciplinar de Ciências Sociais, Faculdade de Ciências Sociais e Humanas, Universidade Nova de Lisboa, Lisboa 1099-085, Portugal 
The growth of urban tourism over the past few years is of special interest for the purposes of this short research paper. Despite the consensus among many authors that urban tourism has brought positive economic impacts to post-industrial cities worldwide over the past three decades (e.g., Crouch \& Ritchie, 1999; Gratton \& Richards, 1996; among others), the growing transnational financialization of both local real estate and the touristification of local nightlife have led to a rise in rental prices and the consequent closure of a significant number of bars, restaurants and clubs (some iconic and even historic). These venues are replaced by either new commercial or leisure premises aimed exclusively at tourism or by new hotels and/or tourist apartments. The current situation in some of the largest European cities is critical. In London, $43 \%$ of the city's music venues closed between 2007 and 2015, while, in the last five years, the number of nightclubs in the city has decreased by $50 \%$ (Cafe, 2016). In Berlin, where there are around 500 nightlife venues and 2,700 parties and events take place every month, the city's nightlife scene is under serious threat. Many venues are rented for 5 or 10 years, and the arrival of new transnational property developers to the city has provoked a real estate boom, particularly in central neighborhoods such as Mitte, Kreuzberg and Friedrichshain. Rental prices for nightlife venues have increased by $20 \%$ over recent years, and many landlords are opting to sell their properties: KitKat Club and Sage Club closed permanently at the end of June 2020, while, in other cases, the construction of new chic residential buildings close to the clubs is forcing the closure of iconic venues (Woolsey, 2019).

However, although many academics from different geographic regions have widely examined the growing interaction between tourism, gentrification and other spatial, social, cultural, and economic processes in today's post-recession cities (e.g., CócolaGant, 2018; Gravari-Barbas \& Guinand, 2017; Hiernaux \& González, 2014), there is still insufficient attention given to the complex, non-linear, multifaceted, continuous interaction (even in opposite directions) between certain urban processes simultaneously taking place in today's "Tourist City". One of these complex urban processes is the touristification of nightlife. In fact, in Berlin, Belgrade, London, Paris, Barcelona, Madrid or Lisbon, among many other "tourist cities" where nightlife is positioned as the central element of urban branding campaigns, the touristification of nightlife and its multifaceted impacts remain underexplored terrain. The text below will argue that the touristification of nightlife is emerging as one of the most aggressive forms of material, symbolic and heritage dispossession of local communities within the central historic neighborhoods of many European cities.

\section{London (de-)calling: unearthing the nights from the peripheries}

Since its publication, Comedia Consultancy's report “Out of Hours: A study of economic, social and cultural life in twelve town centers in the UK" (1991) has been central in building the mainstream discourse that situates the origins of the nighttime leisure economy as the main strategy and mechanism behind the socioeconomic revitalization and urban regeneration of formerly rundown central areas of cities in the late 1980s Britain (e.g., Chatterton \& Hollands, 2003; Law, 2000; Lovatt \& O'Connor, 1995; Roberts, 2006; Roberts \& Eldridge, 2009; Shaw, 2018; among many others). Fortunately, this has recently received new academic input, particularly from peripheral Europe and other 
regions of the world, such as the Eastern Mediterranean, the Americas and Asia (e.g., Buchakjian, 2015; De Góis, 2015; MacArthur-Seal, 2017).

A short chronotopic voyage through the birth of nightlife as a catalyst for the urban regeneration and socioeconomic revitalization of a formerly rundown central urban area would firstly take us to Times Square in New York city in the late 1970s. Crime, drug gangs, sexual exploitation, an incipient patriarchal porn industry and their multiple gritty intersections characterized this city center location that was being devastated by the economic, social and urban effects of the local administration's bankruptcy in the mid-1970s. The brilliant HBO series The Deuce (2017) by David Simon and George Pelecanos presents a chronicle of how Times Square was the first place in the Global North where the nighttime leisure economy - initially dominated by different mafias - developed as a mechanism and strategy to change the face of today's most visited landmark in New York City. At the same time that commercial nightlife emerged as the catalyst for urban, social, and cultural change in central New York, the movida ${ }^{1}$ in Madrid and Lisbon of the early and mid-1980s emerged as new nocturnal scenes in which music, culture, arts and politics merged as synonymous with a cultural, sexual and even political individual and collective liberation following four decades of fascist dictatorship in both Iberian countries (Fouce, 2000; Guerra, 2019). Also in the early 1980s, nightlife was central to the emergence of the Yugo-rock scene in major Yugoslavian cities (e.g., Belgrade, Sarajevo, Split, and Zagreb) which represented a significant cultural and even political (youth) revolution following the death of Josip Broz Tito (Čengić \& MartinDiaz, 2018; Ramet, 2018). Returning once more to the Iberian Peninsula, the birth of makina music in eastern Spain signified a rapid metropolitanization of nighttime leisure practices from the late 1980s (Costa, 2016; Ginesi, 2013), while it also meant a huge step forward in the construction of the island of Ibiza as a world-class nightlife resort (Blázquez \& Morera, 2002; Brewster \& Broughton, 2006). In turn, in the late 1980s once again, some former industrial spaces in Berlin were transformed into some of today's most famous techno music clubs in Europe (Schofield \& Rellensmann, 2015).

The evolution of nightlife in New York, Madrid, Lisbon, Ibiza and Berlin over the past four decades shows us that the geographical origin of the concept "night-time leisure economy" should be situated outside of the United Kingdom and one whole decade before the Comedia report (1991). Moreover, there is an urgent need to explicitly recognize that "the night", and even the "nocturnalization of urban life", are not concepts that exclusively belong to the western world. In fact, the study of the night in Asia, and specifically in China (Chew, 2009; Chongyi, 2007; Farrer, 2008; Song et al., 2016; Zeng, 2009), is crucial for "night studies" scholars in order to widen our knowledge of, among other issues, the complex interplay between tradition, westernized youthful hedonism, embodied state control and East Asian capitalism. As Yeo et al. (2016, p. 383) argue, "nightlife in contemporary Asian cities (...) is shifting toward more globalized forms of entertainment spaces similar in nature to existing trends in Europe and North America. At the same time, however, these Asian cities espouse culturally distinctive urban practices, revealing space-time geographies that are markedly different from nightlife experiences in the West".

Without a doubt, growing knowledge of the urban night in non-western cities is crucial in order to avoid simply "contesting" academic Anglo-dominance - which would be even counterproductive in regards to the goal of widening, spreading and sharing knowledge among we "night studies" scholars - but also regarding the range of new collaborative opportunities to deepen our knowledge about the "Whats", "Whos", "Whys" and "Hows" 
of the vibrant, exciting and multifaceted nights in our global cities in the past, present, and future.

\section{Tourism and nightlife}

Along with the rapid touristification of central urban areas in European capital cities, the rapid and intense expansion of the tourism-oriented nighttime leisure economy (or the touristification of nightlife, as proposed in this text) has involved the emergence of multiple and varied relationships between urban tourism and the economy of "the night". The academic community has started to approach this in recent years (e.g., Eldridge \& Smith, 2019; Giordano et al., 2018; Plyushteva, 2019). However, the study of the "tourist night" is no academic novelty. Since the mid-2000s, a considerable number of authors have given some attention to the behaviors of drugs- and alcohol-fueled patrons during nighttime hours in, for example, Mediterranean nightlife resorts, namely in Ibiza (Spain) and Slanchev Bryag in Bulgaria (Bellis et al., 2003; Carr, 2002; Sönmez et al., 2013; Tutenges, 2012; Tutenges \& Hesse, 2008). Others have focused on the relationship between tourism, the leisure economy and urban change in the "nocturnal city" (Aramayona \& García-Sánchez, 2019; Eldridge, 2019; Nofre et al., 2018; Nofre \& Malet-Calvo, 2019; Nofre et al., 2019; Pinke-Sziva et al., 2019; Roberts, 2006; Roberts \& Eldridge, 2009).

However, as Adam Eldridge (2019, p. 422) argues, “Though studies of urban tourism do not always specifically address nightlife, and likewise studies of the night and nightlife do not always examine tourism, both bodies of research overlap in important ways". Unfortunately, academics have yet to pay sufficient attention to the range of impacts produced by the touristification of the night in many European capitals such as Lisbon, Prague, Paris, Barcelona or Berlin and London (as previously mentioned). As has been widely reported by local, national and some international media sources, the expansion of hotels (or tourist apartments), together with the expansion of new tourist-oriented facilities, have involved the closure of some iconic (even historic) nightlife venues. In addition, the mass arrival of tourists partying without respecting local norms has led to the growing spatial displacement of local partygoers to other (often peripheral) areas of the city, until now unaffected by the pressures of tourism. In other words, while it could be argued that the "forced" spatial displacement of local partygoers to other areas of the city is a material and symbolic dispossession of local communities, the closure of some iconic (even historic) nightlife venues also means the loss of intangible and tangible cultural heritage. All this suggests that the touristification of the night operates (and, therefore, can be examined) on two levels simultaneously ("the spatial" level and "the social" level) and that its main impact is the material, symbolic and heritage dispossession of local communities, as developed in the following section.

\section{The touristification of nightlife: impacts, consequences, and losses}

Through the spatial analytical lens, the touristification of the night is predominantly expressed through three main spatial and economic processes. The first is the growing number of traditional nightlife venues with tourism-oriented facilities such as an ATM next to the bar, and/or the appearance of kitsch ads on venue doors, announcing dozens of exotic, extremely cheap, unhealthy shots, as well as cheap, large, poor-quality cocktails. The second is the arrival of local and transnational real estate investment 
funds, leading to (i) the rapid transformation of entire old buildings - most of which house traditional bars, small dancing bars and/or other locals-oriented nightlife venues - into new 4-5 star hotels and/or tourist apartments; or (ii) their transformation into new (often chic) restaurants, cocktail bars, franchised pubs, or clubs. Thirdly, the touristification of the night can also be confirmed through the notable decrease in the number of bars and restaurants serving local dishes, and their replacement with fusion cuisine, including vegan, vegan-friendly, and "real food" eateries aiming to attract tourists and visitors with more sophisticated and/or sustainable culinary tastes (the relationship between veggie tourism, often linked to alter-capitalist values, and the fight of local communities against the touristification of their neighborhoods, would need much more scholarly attention than it has had to date, since the disappearance of traditional bars and restaurants serving daily meals also means the disappearance of central community meeting places). Therefore, the old restaurants, bars, taverns, pubs, discotheques and clubs that "survive" the process of touristification repurpose their role in the everyday life of the city by becoming one more piece of the city's picturesque scenery, preserving the spirit of the place or, in other words, constructing a retroscape (Brown \& Sherry, 2003) in which tourists are actors in this "colonization of the present by the past" (Belk, 2003, p. 23). ${ }^{2}$

At social level, the touristification of the night is mainly expressed through various parameters. Firstly, the conversion and/or opening of new bars and nightlife for tourists is visually evident upon an initial ethnographic examination of the "new" public frequenting these new tourist venues, the extreme securitization of both the entrance and indoor premises, and the team of young people who work distributing flyers, often only speaking English to potential clients (whether tourists or not). Secondly, the touristification of "the night" entails the coexistence or even the replacement of audiences. In the case of cities with a high degree of tourism such as London, Paris, Lisbon or Barcelona, the mass influx of foreign partygoers has involved the disappearance of local partygoers in (touristified) central areas of the city. However, it should be noted that this substitution of nocturnal audiences not necessarily associated with a gentrification of the night (see examples in: Botta, 2019; Hae, 2011; Malet Calvo et al., 2017; Nofre, 2013). In this sense, it would be valid to consider Quaglieri and Russo (2010) suggestion for the tourist night. According to these authors, the depiction of "the tourist" is not closely related to class, as it is a non-totemic, non-homogeneous figure. In this sense, Sequera and Nofre (2018, p. 6) point out that "many 'common tourists' and visitors might be defined as individuals belonging to middle-lower and working classes in their own home countries". For that very reason, their role as "common tourists" would be supposed not to be "a central symbolic, cultural and economic 'elitist' role regarding a potential process of 'classical gentrification' in the unexplored-terrain-to-be-visited" (Ib.).

The touristification of the night often also involves, either directly or indirectly, competition for the use of nocturnal public space and venue premises, favoring a quick reconfiguration of the neighborhood's social topographies during nighttime hours. Because this "competition" must take place under extreme safety conditions, certain marginal actors of the night (such as street dealers, street drug consumers, older sex workers, and night wanderers with low purchasing power) are displaced - if not violently repressed by police. In the nocturnal tourist city, local marginal actors are seen as perilous social noise for the proper development of the (socially and morally sanitized) 
tourist night. On the other hand, the arrival of large numbers of partygoers to the city's touristified nightlife district involves the rapid worsening of community livability during nighttime hours and the rise of (sometimes violent) conflicts in public spaces during the same hours (e.g., Calafat et al., 2010; Hughes et al., 2009; Nofre et al., 2018; Tutenges, 2009). However, in those areas where residents (i.e. voters) are few, the economic benefits of the touristification of the night are much higher than just electoral benefits for the party (or coalition) ruling the city council. In this case, the worsening of community livability during nighttime hours emerges as one of the main dispositifs - in Foucaultian terminology - of residential displacement.

On the other hand, the closure of traditional nightlife venues means not only the material and symbolic dispossession of local communities but also the loss of the city's tangible and intangible cultural heritage. Firstly, some nightlife venues may house historical-architectural elements of interest and, therefore, should be cataloged and preserved. Secondly, the disappearance of traditional bars, restaurants, clubs and discotheques (or their conversion into new tourist-led facilities) also leads to the destruction of the different community networks of socialization. For many local adult partygoers, dramatic changes brought about by the touristification of the night have involved the emergence of a certain feeling of abandonment, loneliness, and a gradual unfamiliarity with a formerly-well-known and rapidly-changing environment (the "traditional" nightscape). This is of crucial importance, because nightscapes are not only formed by the distribution of nightlife venues and a physical landscape, but above all by multiple networks of "nocturnal sociabilities" (sometimes ephemeral, others more durable) that are formed by numerous memories, experiences, atmospheres, emotions and affectivities. With the touristification of the night, all this becomes relegated to one more minuscule piece of the urban memory, only accessible for those "privileged" (but now displaced) local partygoers who had the opportunity to write a few lines of their city's urban history. However, the closure of "traditional" nightlife venues and the consequent displacement of their local patrons do not only mean the loss of these cities' intangible cultural heritage.

\section{Final remarks: toward a new way of looking at nightlife}

Although a growing number of authors have recently published brilliant works about the "daytime tourist city" and "the right to the city", there is still a gap of scientific knowledge regarding the range of processes taking place in the "nocturnal tourist city". This paper has presented some initial theoretical notes about how the touristification of nightlife is emerging as one of the most aggressive forms of material, symbolic and heritage dispossession of local communities in the central historic neighborhoods of many European cities.

Another research topic with enormous potential for discussion is the fact that, in some European cities, the touristification of nightlife can be seen to be a disruptive process of urban change. Interestingly, the use here of the term "disruptive" is not superfluous. While many authors argue that touristification and gentrification coexist simultaneously in many European cities (e.g., Gravari-Barbas \& Guinand, 2017), the ethnographic fieldwork conducted by the author of this paper on the nightlife of Barcelona (Catalonia) and Lisbon (Portugal) over the last 15 and 10 years, respectively, ${ }^{3}$ allows us to suggest that the touristification of the night in the historic neighborhoods of the city center in both cities has disrupted the process of nightlife gentrification that was played out by middle and upper-middle class locals, 
and that began in both areas in late 1990s (e.g., La Barceloneta in Barcelona) and mid-2010s (e.g., Bairro Alto and Cais do Sodré in Lisbon) (Nofre, 2013; Nofre et al., 2018, 2017).

The touristification of the night therefore acts as a disruptive mechanism of spatial, social and cultural change in the urban fabric of the "nocturnal city". In particular, in both cities those nightlife gentries (middle and upper-middle class locals) who over the past two decades have colonized the night in formerly rundown historic neighborhoods of the city center - after many years of crime, petty drug dealing, marginal prostitution, urban poverty, social exclusion and some episodes of violence during nighttime hours have disappeared from central nightlife areas of both aforementioned cities. In Raval, Gòtic or Barceloneta (in Barcelona), or Bairro Alto and Cais do Sodré (in Lisbon), local upper-middle classes no longer participate in "the night" of these "tourist districts".

Interestingly, however, although the substitution by new transnational partygoers with lower purchasing power constitutes a concern for local nightlife entrepreneurs, the emergence of new conflicts - with different narratives, grammars and intensities between locals and tourists regarding the appropriation and use of public spaces and nightlife venues, reveal the fundamental question about nightlife touristification: Who does the nocturnal tourist city belong to?

In this sense, and with the aim of reversing the range of negative processes driven by disruptive nightlife touristification in our cities, it appears essential to underline the social and cultural value of the night. In spite of multiple attempts by the private nightlife sector to emphasize this facet of "the night", in the last lines of this paper we would like to claim a new institutional approach to "the night". It is at this point that academia is supposed to play a fundamental role by designing and implementing a more than necessary research agenda on the "nocturnal tourist city" that should aim to not only establish its focus on the monitoring and analysis of the socio-spatial change involved in nightlife touristification in central urban areas, but also (and especially) enhance the social and cultural value of nightlife, which is often a source of socio-emotional wellbeing, inclusion and community-building in Global South and North societies alike.

\section{Notes}

1. In fact, there were many movidas across 1980s Spain, especially in small cities and towns of the country such as in Vigo, Gijón, Bilbao, Iruña, Zaragoza, among many others.

2. One example of this is the historical neighborhood of Alfama, in Lisbon city center (Sequera \& Nofre, 2020).

3. With the aim of avoiding excessive self-citation, please see author's academic profiles (i.e. Academia and ResearchGate).

\section{Acknowledgments}

The authors wish to express their special gratitude to all informants who agreed to participate in our research.

\section{Disclosure statement}

No potential conflict of interest was reported by the author. 


\section{References}

Aramayona, B., \& García-Sánchez, R. (2019). Decoding middle-class protest against low-cost nocturnal tourism in Madrid. Journal of Policy Research in Tourism, Leisure and Events, 11 (3), 380-393. https://doi.org/10.1080/19407963.2019.1584627

Belk, RW. (2003). The sims and the retro future. In S. Brown \& J. F. Sherry (Eds.), Time, space, and the market: Retroscapes rising (pp. 35-53). M.E. Sharpe Publishers.

Bellis, M. A., Hughes, K., Bennett, A., \& Thomson, R. (2003). The role of an international nightlife resort in the proliferation of recreational drugs. Addiction, 98(12), 1713-1721. https://doi.org/ 10.1111/j.1360-0443.2003.00554.x

Bianchini, F. (1990). Flagship projects in urban regeneration. Centre for Urban Studies, University of Liverpool.

Bianchini, F. (1995). Night cultures, night economies. Planning Practice \& Research, 10(2), 121-126. https://doi.org/10.1080/02697459550036667

Blázquez, J., \& Morera, O. (2002). Loops. Una historia de la música electrónica. Reservoir Books.

Botta, G. (2019). Night time studies, gentrification and Helsinki. Yhdyskuntasuunnittelu-lehti, 57 (4), 48-52. https://doi.org/10.33357/ys.88630

Brewster, B., \& Broughton, F. (2006). Last night a DJ saved my life: The history of the disc jockey. Grove/Atlantic.

Brown, S., \& Sherry, J.F., Jr. (Eds). (2003). Time, space, and the market: Retroscapes rising. Routledge.

Buchakjian, G. (2015). Beirut by Night: A Century of Nightlife Photography. Middle East Journal of Culture and Communication, 8(2-3), 256-281. https://doi.org/10.1163/18739865-00802006

Cafe, R. (2016, October 7). Last call: What's happened to London's nightlife? BBC News. Retrieved December 13, 2019, from. https://www.bbc.com/news/uk-england-london-37546558>

Calafat, A., Blay, N., Belis, M, Hughes, K., Kokkevi, A., Mendes, F., Cibin, B., Lazarov, P., Bajcarova, L, Boyiadjis, G., Duch, M.A., Juan, M., Magalhàes, C.C., PavlakisIoanna, A., Siamou, I., Stamos, A., \& Tripodi, A. (2010). Tourism, nightlife and violence: A cross cultural analysis and preventive recommendations. IREFREA.

Carr, N. (2002). A comparative analysis of the behaviour of domestic and international young tourists. Tourism Management, 23(3), 321-325. https://doi.org/10.1016/S0261-5177(01) 00089-9

Čengić, N., \& Martin-Diaz, J. (2018). Night-time economy and urban development in postsocialist Sarajevo. In J. Nofre \& A. Eldridge (Eds.), Exploring nightlife: Space, society \& governance (pp. 53-67). Rowman \& Littlefield International.

Chatterton, P., \& Hollands, R. (2003). Urban nightscapes: Youth cultures, pleasure spaces and corporate power. Routledge.

Chew, M. M. (2009). Research on Chinese nightlife cultures and night-time economies: Guest editor's introduction. Chinese Sociology \& Anthropology, 42(2), 3-21. https://doi.org/10.2753/ CSA0009-4625420200

Chongyi, F. (2007). From barrooms to teahouses: Commercial nightlife in Hainan since 1988. In J. Wang (Ed.), Locating China: Space, place \& popular culture (pp. 147-163). Routledge.

Cócola-Gant, A. (2018). Tourism gentrification. In L. Lees \& M. Phillips (Eds.), Handbook of gentrification studies (pp. 281-293). Routledge.

Comedia Consultancy. (1991). Out of hours: A study of economic, social and cultural life in twelve town centres in the UK - Summary report.

Costa, L. (2016). ¡Bacalao!: Historia Oral de la Música de Baile en Valencia, 1980-1995. Contraediciones.

Crouch, G. I., \& Ritchie, J. B. (1999). Tourism, competitiveness, and societal prosperity. Journal of Business Research, 44(3), 137-152. https://doi.org/10.1016/S0148-2963(97)00196-3

De Góis, M. P. F. (2015). 'Na Calada da Noite': Modernidade e conservadorismo na vida noturna Carioca (1760-1950). Espaço Aberto, 5(2), 49-60. https://doi.org/10.36403/espacoaberto.2015.2690 
Eldridge, A. (2019). Strangers in the night: Nightlife studies and new urban tourism. Journal of Policy Research in Tourism, Leisure and Events, 11(3), 422-435. https://doi.org/10.1080/ 19407963.2019.1583666

Eldridge, A., \& Smith, A. (2019). Tourism and the night: Towards a broader understanding of nocturnal city destinations. Journal of Policy Research in Tourism, Leisure and Events, 11(3), 371-379. https://doi.org/10.1080/19407963.2019.1631519

Farrer, J. (2008). Play and power in Chinese nightlife spaces. China: An International Journal, 6(1), 1-17. https://doi.org/10.1142/S0219747208000034

Fouce, H. (2000). La cultura juvenil como fenómeno dialógico: Reflexiones en torno a la movida madrileña. CIC. Cuadernos deInformación y Comunicación, 5, 267-275. Retrieved February 10, 2020, from, http://www.redalyc.org/articulo.oa?id=93500515

Ginesi, G. (2013). ¡Baila toda la noche! In S. Martínez \& H. Fouce (Eds.), Made in Spain: Studies in popular music (pp. 135-143). Routledge.

Giordano, E., Nofre, J., \& Crozat, D. (2018). La touristification de la vie nocturne: Une nouvelle frontière pour la recherche sur la nuit urbaine. Cybergeo: European Journal of Geography. Retrieved February 11, 2020, from. https://journals.openedition.org/cybergeo/29473

Gratton, C., \& Richards, G. (1996). The economic context of cultural tourism. In G. Richards (Ed.), Cultural tourism in Europe (pp. 71-87). CAB International.

Gravari-Barbas, M., \& Guinand, S. (Eds.). (2017). Tourism and gentrification in contemporary metropolises: International perspectives. Taylor \& Francis.

Guerra, P. (2019). Rádio Caos: Resistência e experimentação cultural nos anos 1980. Análise Social, 231, 284-309. http://dx.doi.org/10.31447/AS000032573.2019231.03

Hae, L. (2011). Dilemmas of the nightlife fix: Post-industrialisation and the gentrification of nightlife in New York City. Urban Studies, 48(16), 3449-3465. https://doi.org/10.1177/ 0042098011400772

Haslam, D. (2015). Life after dark: A history of British nightclubs \& music venues. Simon and Schuster.

Hiernaux, D., \& González, C. I. (2014). Turismo y gentrificación: Pistas teóricas sobre una articulación. Revista De Geografía Norte Grande, 58, 55-70. https://doi.org/10.4067/S071834022014000200004

Hughes, K., Bellis, M. A., Whelan, G., Calafat, A., Juan, M. \& Blay, N. (2009). Alcohol, drugs, sex and violence: Health risks and consequences in young British holidaymakers to the Balearics. Addicciones, 21(4), 265-277

Laughey, D. (2006). Music and youth culture. Edinburgh University Press.

Lovatt, A., \& O'Connor, J. (1995). Cities and the night-time economy. Planning Practice \& Research, 10(2), 127-134. https://doi.org/10.1080/02697459550036676

MacArthur-Seal, D. J. (2017). Intoxication and imperialism: Nightlife in occupied Istanbul, 1918-23. Comparative Studies of South Asia, Africa and the Middle East, 37(2), 299-313. https://doi.org/10.1215/1089201x-4132917

Malet Calvo, D., Nofre, J., \& Geraldes, M. (2017). The Erasmus Corner: Place-making of a sanitised nightlife spot in the Bairro Alto (Lisbon, Portugal). Leisure Studies, 36(6), 778-792. https://doi. org/10.1080/02614367.2016.1271821

Nofre, J. (2013). Vintage nightlife: Gentrifying Lisbon downtown. Fennia: International Journal of Geography, 191(2), 106-127. https://doi.org/10.11143/8231

Nofre, J., \& Malet-Calvo, D. (2019). Pubcrawling Lisbon: Nocturnal geoethnographies of Bairro Alto. In G. Botta \& G. Stahl (Eds.), Nocturnes: Popular music and the night (pp. 49-61). Palgrave MacMillan.

Nofre, J., Giordano, E., Eldridge, A., Martins, J. C., \& Sequera, J. (2018). Tourism, nightlife and planning: Challenges and opportunities for community liveability in La Barceloneta. Tourism Geographies, 20(3), 377-396. https://doi.org/10.1080/14616688.2017.1375972

Nofre, J., Martins, J.C., Vaz, D., Fina, R., Sequera, J., \& Vale, P. (2019). “The 'pink street' in Cais do Sodré: Urban change and liminal governance in a nightlife district of Lisbon. Urban Research \& Practice, 12(4), 322-340. https://doi.org/10.1080/17535069.2018.1449010 
Nofre, J., Sánchez-Fuarros, I., Malet-Calvo, D., Martins, J.C., Pereira, P., Soares, I., Geraldes, M., \& López-Díaz, A. (2017). Exploring nightlife and urban change in Bairro Alto, Lisbon. City \& Community, 16(3), 330-344. https://doi.org/10.1111/cico.12248

Pinke-Sziva, I., Smith, M., Olt, G., \& Berezvai, Z. (2019). Overtourism and the night-time economy: A case study of Budapest. International Journal of Tourism Cities, 5(1), 1-16. https://doi.org/10.1108/IJTC-04-2018-0028

Plyushteva, A. (2019). Commuting and the urban night: Nocturnal mobilities in tourism and hospitality work. Journal of Policy Research in Tourism, Leisure and Events, 11(3), 407-421. https://doi.org/10.1080/19407963.2018.1556673

Quaglieri, A, \& Russo, P. (2010). Paisajes urbanos en la época post-turística. Propuesta de un marco analítico. Scripta Nova. Revista Electrónica de Geografía y Ciencias Sociales, 14(3239). http://www.ub.es/geocrit/sn/sn-323.htm

Ramet, S. P. (2018). Balkan Babel: The disintegration of Yugoslavia from the death of Tito to the fall of Milosevic. Routledge.

Roberts, M. (2006). From 'creative city' to 'no-go areas': The expansion of the night-time economy in British town and city centres. Cities, 23(5), 331-338. https://doi.org/10.1016/j.cities.2006.05. 001

Roberts, M., \& Eldridge, A. (2009). Planning the night-time city. Routledge.

Schofield, J., \& Rellensmann, L. (2015). Underground heritage: Berlin techno and the changing city. Heritage \& Society, 8(2), 111-138. https://doi.org/10.1080/2159032X.2015.1126132

Sequera, J., \& Nofre, J. (2018). Shaken, not stirred: New debates on touristification and the limits of gentrification. City, 5(6), 843-855. https://doi.org/10.1080/13604813.2018.1548819

Sequera, J., \& Nofre, J. (2020). Touristification, transnational gentrification and urban change in Lisbon: The neighbourhood of Alfama. Urban Studies, 57(15), 3169-3189. https://doi.org/10. $1177 / 0042098019883734$

Shaw, R. (2018). The nocturnal city. Routledge.

Song, H., Pan, M., \& Chen, Y. (2016). Nightlife and public spaces in urban villages: A case study of the Pearl river delta in China. Habitat International, 57, 187-204. https://doi.org/10.1016/j. habitatint.2016.07.009

Sönmez, S., Apostolopoulos, Y., Theocharous, A., \& Massengale, K. (2013). Bar crawls, foam parties, and clubbing networks: Mapping the risk environment of a Mediterranean nightlife resort. Tourism Management Perspectives, 8, 49-59. https://doi.org/10.1016/j.tmp.2013.05.002

Tutenges, S. (2009). Safety problems among heavy-drinking youth at a Bulgarian nightlife resort. International Journal of Drug Policy, 20(5), 444-446. https://doi.org/10.1016/j.drugpo.2008.11. 004

Tutenges, S. (2012). Nightlife tourism: A mixed methods study of young tourists at an international nightlife resort. Tourist Studies, 12(2), 131-150. https://doi.org/10.1177/ 1468797612454250

Tutenges, S., \& Hesse, M. (2008). Patterns of binge drinking at an international nightlife resort. Alcohol \& Alcoholism, 43(5), 595-599. https://doi.org/10.1093/alcalc/agn039

Woolsey, B. (2019, December 5). Berlin's notorious fetish club may be forced to close. The Guardian. Retrieved January 21, 2020, from. https://www.theguardian.com/travel/2019/dec/ 05/berlin-notorious-fetish-club-may-be-forced-to-close

Yeo, S. J., Ho, K. C., \& Heng, C. K. (2016). Rethinking spatial planning for urban conviviality and social diversity: A study of nightlife in a Singapore public housing estate neighbourhood. Town Planning Review, 87(4), 379-399. https://doi.org/10.3828/tpr.2016.26

Zeng, G. (2009). The transformation of nightlife districts in Guangzhou, 1995-2009. Chinese Sociology \& Anthropology, 42(2), 56-75. https://doi.org/10.2753/CSA0009-4625420203 